\title{
Alumni's perceptions about commitment towards their university: drivers and consequences
}

\author{
Ilda Maria Pedro ${ }^{1,2}$ (D) - Júlio Costa Mendes ${ }^{2,3}$ (D) - Luis Nobre Pereira ${ }^{2,4}$ (D) \\ Bernardete Dias Sequeira ${ }^{3,5}$ (D)
}

Received: 13 April 2020 / Accepted: 6 August 2020 / Published online: 17 August 2020

C) Springer-Verlag GmbH Germany, part of Springer Nature 2020

\begin{abstract}
This paper intends to capture alumni's assessments and perceptions about decisive dimensions of their commitment towards their alma mater. Their academic experience and current situation are highlighted. Moreover, their perception about the role of Higher Education Institution (HEI) in this commitment-relationship is likewise valuable to get their involvement. The study took place at a Portuguese university. Three focus groups, with 21 participants, were conducted to get consistent information permitting further developments. Data were analysed through NVivo software.The study gives insights revealing dimensions such as the relationships with teachers, extracurricular activities and initiation as decisive in their academic experience. Recommending and sharing their experience, underline evidence of what they are willing to give back. Moreover, their consciousness of bearing a mission to contribute to HEI's development was expressed through strong positive feelings, such as the sense of belonging, and pride at being part of the university, defined in their statements. But they all demand an effective ability of the university to communicate with them. Overall conclusions offer a scenario of alumni's commitment, giving HEI's management valuable clues to improvement, but its responsibility in this commitmentrelationship was also stressed. Moreover, results also provide contributions to literature enabling other HEIs to replicate the study or simply use the results for their own development. Since the study occurred in a relatively weak alumni culture context, revealing the importance in promoting debate as a means to engage alumni in HEI's efforts for success, it presents insights for further developments in similar higher education environments.
\end{abstract}

Keywords Relationship marketing · University · Alumni · Commitment-relationship · Perceptions · Focus group

Ilda Maria Pedro

ipedro@ualg.pt

Extended author information available on the last page of the article 


\section{Introduction}

The global knowledge economy defines new and complex challenges to the education market, with particular emphasis in the third sector, as it must rapidly respond to profound changes in its environment. European Higher Education Institution (HEIs) face a context of increasing competition, financial difficulties and demographic changes, which require innovative responses to achieve competitiveness, and marketization has been definitively one of them.

HEIs' role goes beyond teaching and research, as they are central pillars in economic and social development as service providers (Schlesinger et al. 2015). Relationships with their stakeholders have become a core issue among the strategies to keep HEIs in a competitive position, which is supported by a more professional management structure, based in a customer-driven culture (Oplatka and Hemsley-Brown 2007).

Relationship marketing (RM) frames approaches to students as main stakeholders, in order to strengthen their loyalty. A loyal student will become a loyal alumnus in the future, and the long term-relationships with alumni will provide significant benefits to HEIs (e.g. Alwi and Kitchen 2014; Helgesen and Nesset 2007; Hennig-Thurau et al. 2001; Pedro and Andraz 2019; Snijders et al. 2019). To sustain such relationships, both alumni and HEI must be strongly committed to it. The higher the commitment, the more the intention to remain in the relationship (Morgan and Hunt 1994). Commitment consists of affective and cognitive features, explaining individual attitudes and behaviour in a relationship (Nora and Cabrera 1993; Sargeant and Woodliffe 2005). HEIs' administrators must clearly understand determinants and consequences of alumni's commitment and in different countries, they have been studying their alumni (Pedro et al. 2020; Skari 2014).

This premise sets the starting point of this study, catching their opinions and feelings about a set of questions that may define their commitment. Therefore, three main objectives were set for this study. First, to promote a debate through focus groups in order to understand alumni's opinions and perceptions about a set of topics related with commitment towards their alma mater. Second, to understand if this strategy represents an efficient means to involve alumni and get their collaboration. Third, to collect valuable information about drivers and consequences of commitment in such a way that a theoretical framework can arise to guide future studies.

This research took place at a Portuguese university. A qualitative study was conducted through alumni focus groups. Data analysis took place through NVivo software. According to related literature and bearing in mind the purposes of this study, analysis took into consideration the following dimensions: (1) academic experience (AE) identifying the decisive factors that influence commitment (e.g. Helgesen and Nesset 2007; Newman and Petrosko 2011; Pedro et al. 2018; Koenig-Lewis et al. 2016); (2) after graduation (current situation) - aspects that may influence the willingness to commit (e.g. Belfield and Beney 2000; Clotfelter 2001; Newman and Petrosko 2011); (3) kinds of giving back - identification of the different ways alumni can give their collaboration to university (e.g. Alwi and Kitchen 2014; Iskhakova et al. 2016; Snijders et al. 2019; Pedro et al. 2020); (4) university's commitment towards them - what they expect from the university (e.g. Bernal and Mille 2013; Pedro et al. 2020; Skari 2014).

The alumni-alma mater commitment-relationship represents a profitable field for research, and these results provide HEIs with data to take into account when making 
accurate decisions. We believe that this study will bring interesting theoretical contributions, namely at the strategies definition level in order to intensify and maintain relationships with alumni, particularly important in higher education contexts where those relationships are not a tradition. As far as we know this is a pioneering study in the context where it was applied. It reveals the value in promoting debate as a means to engage alumni in HEI's efforts for success, and presents valuable insights for further developments in similar contexts especially on what concerns Portuguese HEIs, which till recently, were characterized through reactive attitudes towards their stakeholders (Mainardes et al. 2014).

This paper is organized as follows: the next section presents the literature review, followed by an in-depth presentation of the methodology; the third section presents the results and a discussion of the findings; the conclusions and implications are presented in the fourth and fifth sections, followed by section six comprising the limitations and the suggestions for further research.

\section{Literature review}

Marketing concepts have been implemented in the daily strategies of higher education (HE) sector, underlying a brand new language among management routines. A widespread marketization of $\mathrm{HE}$ responds to internationalization and globalization (Hemsley-Brown and Oplatka 2006). Furthermore, assertive responses to growing demands on their mission, together with financial and management efficiency concerns, must be found (e.g. Alves and Raposo 2007; Helgesen and Nesset 2007). The role of HEIs upon society development is framed by the production and transference of knowledge and innovation. The efficiency and skills they put into this process, along with the constant improvement shown, embody the challenge to achieve competitiveness (e.g. Bleiklie et al. 2012; Donina and Hasanefendic 2018).

Literature on education marketing first appeared in the USA and UK. Initial studies were conducted back in the seventies and eighties, when terms like marketing and marketing research entered the academic world, borrowed from the business context (Litten 1980). Works developed at the time were theoretical-normative in nature and based on models for business purposes (Hemsley-Brown and Oplatka 2006). Moreover, marketing approaches in HEIs were far from being in accord, due to the duality in the interpretation of students as customers and as products in the educational process (Litten 1980; Conway et al. 1994). The connotation of marketing with a pure business context threatening the values of education as commercial values of competition, were incompatible with the goal to provide equal opportunities for learning development (Harvey 1996). Furthermore, marketing was often assumed as merely advertisements and public relations (Hemsley-Brown and Oplatka 2006).

On the nineties, HE was seen as a pure element of the services sector. Education is primarily "people based", rather than "equipment based" (Mazzarol and Soutar 1999). Canterbury (2000) recognizes that educational services have the same characteristics as those in the service industry. However, the inherent complexity of the service delivered demands serious prudence in the transfer of methods used in the business sector to the HE field. The choice of the institution that Canterbury (2000) calls the "unique decision", the lack of information in what to look for, and 
the influence and the effect of family matters on that choice are pieces in a complex puzzle that frame marketers' decisions.

Students, must be attracted and retained in a very competitive market (Kotler and Fox 1994). The capability of retaining students can be defined as the securing of students' loyalty and the certainty of their satisfaction. The focus lies now on fostering relationships (defensive marketing) instead of acquisition (offensive marketing) (Helgesen 2008). A different approach, through a customer-driven culture (Martin et al. 2015; Oplatka and Hemsley-Brown 2007), relies on relationship marketing. Institutions realize the importance of economic customer values that arise in this process (Grönroos 1994), and this important concept drives marketing strategies in the HE market as it stresses a strong competitive advantage. When students understand the values embedded in an educational service, they commit to the relationship (Alves and Raposo 2007; Helgesen and Nesset 2007; Rojas-Méndez et al. 2009). Having committed students gives HEIs' advantages, as they can positively influence the quality of teaching and research development and, later, they become committed alumni (Hennig-Thurau et al. 2001).

Sociological and psychological perspectives explain commitment in human relations (Sargeant and Woodliffe 2005). Whereas for sociologists, commitment is framed by social factors that compel individuals to perform a consistent action, psychologists explain commitment by decisions that tend to maintain a behaviour (Sargeant and Woodliffe 2005).

Commitment has been widely studied some examples are given in studies of Amani 2015; Fullerton 2003; Huselid and Day 1991; Morgan and Hunt 1994; Nora and Cabrera 1993; Pedro et al. 2020, 2018), and strong contributions appear in an RM context, through research applied in industrial and commercial organizations. A few examples are the studies of Huselid and Day (1991), where the interactions between organizational commitment and involvement were considered to predict turnover. Mowday et al. (1979) put the focus on measuring attitudinal commitment in organizations to ascertain how it is related to employee behaviour. Organizational commitment encompasses items such as: affinity; values; the certainty of having done a good choice; loyalty and sense of belonging to the organization (Nora and Cabrera 1993). Grossman (1999) stated that commitment is the feeling of being voluntarily tied to a firm.

The commitment-relationship in a relational exchange tended to be valorised if the partners recognize benefits coming from the extent of it. Geyskens et al. (1996) describe commitment as a nuclear element for successful RM, and therefore the research targets are the factors that contribute to the maintenance, development and enhancement of commitment. Because commitment is the intention to guarantee the relationship, different motivations can underlie this intention, which implies different types of commitment. These authors stress affective (emotional) and calculative (cognitive) commitment as psychological states. Affective commitment is related to the appreciation of a relationship, whereas calculative commitment refers the perception of the inherent switching costs of leaving it.

When applied to HEIs, and concerning relationships with alumni, both affective and cognitive commitment are clearly identified. The nature of alumni commitment is rooted in a sense of belonging, shared values and identification with their alma mater; in other words, affective commitment. Furthermore, the alumni-alma mater relationship is also assessed in terms of switching costs and benefits, stressing the calculative 
dimension through different services they expect from HEIs, in terms of career advice, consulting support and free library access, among many others (Alnawas and Phillips 2015; Hennig-Thurau 2001; Iskhakova et al. 2016). The skill to offer benefits and value to their students and alumni gives HEIs advantages in building strong relationships (Ravald and Grönroos 1996).

Commitment is mostly influenced by AE. A set of experiences at this period of a student's lifetime defines feelings about and relationships with their alma mater (Gaier 2005; McAlexander and Koenig 2001). These feelings enhance the sense of belonging and oneness through the identification with the university in general (Wilkins and Huisman 2013; Mael and Ashforth 1992). Mentioned experiences are multi-dimensional, considering all the educational resources offered, such as the course itself, support services, campus facilities and campus life, among many others (Browne et al. 1998; Elliott and Shin 2002).

Alumni assess their AE, evaluating the resources at their disposal, the quality of service received and the establishment of interpersonal relationships (Gaier 2005; McAlexander and Koenig 2001; Pedro et al. 2020). Outcomes of this assessment forge different dimensions like satisfaction, image, trust, values and quality (e.g. Newman and Petrosko 2011; Brown and Mazzarol 2008; McAlexander et al. 2003).

Commitment is a determinant of the cooperative behaviour (e.g. Iskhakova et al. 2016; Pedro et al. 2020). In terms of the alumni-alma mater relationship, it encompasses different facets, such as: willingness to recommend; selection of the institution for further study; joining the alumni association; voluntary support; mentoring; keeping in touch; receiving the newsletter; and influencing through their professional and personal connections (e.g. Iskhakova et al. 2016; Gallo 2012; Alwi and Kitchen 2014; Helgesen and Nesset 2007; Weerts and Ronca 2007). Pedro et al. (2018) highlighted the following elements in alumni commitment: (1) willingness to continue training; (2) recommendation of institution and the course; (3) participation; and (4) sense of belonging.

In a calculative perspective, alumni expect to receive all sorts of benefits and services from the institution (Alnawas and Phillips 2015). A long-term commitmentrelationship depends on successful programmes to attain and retain gradual alumni involvement in the institution (McAlexander and Koenig 2001). To assure the effectiveness of initiatives, HEIs are challenged to know their alumni, namely, identifying the variables that most influence giving and clearly understanding who is willing to give back (Henning 2012; Pedro et al. 2018; Tom and Elmer 1994).

The present study is conducted bearing this in mind. Empirical research in southern European countries is important, as it will contribute to developments in alumni affairs and may capture different features. The following sections present the empirical developments of this study.

\section{Methodology}

\subsection{Research context}

The research took place at the University of Algarve, a Portuguese HEI that began its activity in 1979 and encompasses both systems: polytechnic and university. Through to 
present day, it has had around 30,000 alumni. The alumni office began its activities in 2009. Some important initiatives have already been undertaken towards the alumni engagement, such as: a mentorship programme; alumni career award; alumni council; and alumni meetings. Approaches concerning the development and reinforcement of those relationships make up part of the institution's strategic plan. The lack of consistent information about alumni relationships is still a limitation when it comes to defining effective marketing strategies.

\subsection{Research strategy and instrument development}

A qualitative study took place to collect the alumni point of view and to get a closer understanding of the sense of their actions related to commitment-relationship determinants and consequences. It was also aimed at catching their expectations about the university's role in this commitment-relationship. This is an intrinsic case study, as the researcher aims for a deeper comprehension of a particular case that possessives investigative interest (Stake 1995).

The qualitative approach enables a clarification of the phenomenon through the following perspectives: in epistemological terms, it leads to an understanding of the interpretation participants have of those dimensions; in the ontological point of view, it stresses the role alumni play on the outcomes of this reality and provides an inductive view of the relationship between theory and research (Bryman 2012).

The focus group technique was used to collect data. This technique provides inductive reasoning, allowing the researcher to gain a thorough and comprehensive understanding of the research topic. It took place in December 2017 and January 2018 in the university facilities. A first contact inviting participants was made two weeks in advance, giving general explanation about the study and their role in it. A few days before each meeting, participants were given deeper information to avoid misunderstandings. The researcher received informed consent from all participants and also clearly stated that they could withdraw from the study at any point. A moderately structured interview guide was produced according to the literature, as shown in Table 1. Moderation was conducted by a team of two: a researcher that guided the interviews and a second assistant that helped with some direct transcription of main topics and relevant annotations which emerged during the conversation.

Each focus group discussion was scheduled for $90 \mathrm{~min}$, but went beyond this schedule by about 15 min for each group. Participants' responses were audio recorded, and a verbatim transcription was made afterwards. First, every perceptible sentence was transcribed in the record, leaving blank spaces when the sound was not clear; then a review was done in order to fill blank spaces and, finally, a clear text was written, with proper grammar in place and useless elements suppressed (Guerra 2006).

\subsection{Sampling features}

The sample comprised 21 individuals covering a time range from 1995 to 2012. A purposive sample was used to cover as much as possible of the different features of the graduates (e.g. graduation years; both systems university and polytechnic; alumni of night and normal schedules; representation of all formation areas; volunteers). 
Table 1 Interview guide

\author{
Introductory question \\ Introduces the main theme and leads \\ participants to reflect on a past experience \\ and its connection with the topic \\ Key issues \\ These are the questions that lead to the study
}

What do you remember the most about your time as a student?

Question 1. In your opinion, what are the main aspects, resulting from that time as a student, that may influence your collaborative relationships with the university?

Question 2. What kind of collaboration are you willing to give?

Question 3. Taking into account your current situation, what are the most important aspects that may influence on your connection to the university?

Question 4. What do you expect from the university, in this collaborative relationship?

Regarding the participants in the focus groups, 12 were women, and their age ranged from 28 to 53 years old (Mean $=39, \mathrm{SD}=7.4$ ), and 13 usually participate in the alma mater activities. Of the participants, 10 were from the polytechnic, and 11 from the university system.

\subsection{Data analysis}

Data were treated through content analysis. Thematic analysis allowed a better understanding of the central meanings, including reading and rereading of the transcripts to the themes identified. Codification was conducted taking into consideration the four dimensions of the study, and categories and subcategories emerged (Guerra 2006), regarding exclusiveness - each element belongs exclusively to a category, and exhaustiveness - language data represents all recording units without exception (Stemler 2001). Bardin (1977) adds some more requirements to assure quality in codification: homogeneity - each category demands its own analysis dimension; relevance - a category is relevant when it fits to the analysis method and it belongs to the previous theoretical frame; and objectivity and fidelity - the researcher must clearly define variables as well as the criterion to include them in specific categories. A semantic criterion was used to classify every recording unit (Bardin 1977).

Categories were established through a rigorous examination of statements and framed by literature and respecting the aforementioned principles. As an instance the category "Teachers" as the most mention word (88 quantitative references in NVivo counts), appeared regarding answers to all questions. However, for categorization purposes, researchers were helped by semantic and homogeneity criterions, and due to its relevancy concerning $\mathrm{AE}$ it was thought to characterize this dimension. At the same time, objectivity and fidelity principles were respected, because the word was strongly associated with aspects related to their memories as students. As Clark and Vealé (2018) state, researchers must avoid personal assumptions and biases regarding the topic. Three phases of coding and categorization took place. Firstly, analysis was 
conducted based on the theoretical frame of each dimension in the study, but the goal was also to eventually discover specific categories from which to draw a conceptual framework, and therefore inductive and deductive analysis and constant comparison were used; afterwards, there was a second, more accurate, analysis aiming for a deeper understanding and a rearrangement of categories to establish a clear link between data and the ideas (Saldaña 2009), which led to reducing the number of categories. Finally, a more refined reflection about the categories identified justifies reclassification of some coded data into different categories and subcategories. Results of this development are shown in Table 2.

The NVivo Pro Version 11 software was used to analyse the data.

\section{Results and discussion}

The results underline a set of categories that we can easily identify in the literature (e.g. Helgesen and Nesset 2007; Iskhakova et al. 2016, McAlexander and Koenig (2001); Newman and Petrosko 2011; Skari (2014); Pedro et al. 2020) drawing out parallelisms with other studies, revealing an overview of some determinant themes that emerged in participants' statements. Table 2 shows these categories and subcategories, as well as some main references to the theoretical frame. Quantitative references refer to NVivo counts.

Academic experience was explored in Q.1, and it was by far the most discussed item. All the participants expressed significant nostalgia when sharing their memories. Martin et al. (2015) refer to the need to consider nostalgia in future research as an important construct concerning the impacts on alumni-brand-community relationships. This dimension revealed five main categories presenting the hierarchy displayed in Fig. 1. This section contains the analysis of categories and includes a few participants' sentences. Codification at the beginning of each sentence identifies the group $(\mathrm{G})$ and the individuals (I).

References to teachers transmit either satisfaction or no satisfaction at all and are related to some important aspects, such as quality of teaching, which is described in terms of pedagogic and scientific competence. The capacity of teachers to welcome them and their empathy towards specific situations were also mentioned. They feel that there was a deep understanding about their situation and feel satisfied as a result. There is also recognition that some teachers motivated them. There were a few statements underlining the influence teachers had on them, and they remember it as a good thing

G3. I3 "I appreciated the understanding revealed by my teachers relating to my status as a student worker... It was easy to reached them when it was necessary... When I look back I have a pleasant memory of an institution that somehow facilitated my life."

G1. I11 "I remember teachers who motivated us especially through activities developed during classes $[\ldots] "$

G1. I12 "There were many teachers who had a great influence on me $[\ldots] "$

Acknowledging teachers as a significant item in alumni memories is in accordance with the literature, and it seems to be related to the fact that students spend much of 
Table 2 Codification and categorization

\begin{tabular}{|c|c|c|c|c|}
\hline Dimension & Category & Subcategory & Refe. & References \\
\hline \multirow[t]{5}{*}{$\begin{array}{l}\text { Academic } \\
\text { experience }\end{array}$} & Teachers & $\begin{array}{l}\text { Quality } \\
\text { Empathy } \\
\text { Motivation }\end{array}$ & 88 & $\begin{array}{l}\text { e.g. Elliott and Healy (2001); } \\
\text { Helgesen and Nesset (2007); } \\
\text { Elsharnouby (2015) }\end{array}$ \\
\hline & $\begin{array}{l}\text { Extracurricular } \\
\text { activities }\end{array}$ & $\begin{array}{l}\text { Life in campus } \\
\text { Extra activities } \\
\text { related to } \\
\text { course program }\end{array}$ & 31 & $\begin{array}{l}\text { e.g. Skari (2014); Newman and } \\
\quad \text { Petrosko (2011); Clotfelter (2001) }\end{array}$ \\
\hline & Relationships & $\begin{array}{l}\text { Teachers } \\
\text { Fellow colleagues } \\
\text { Nonacademic staff }\end{array}$ & 27 & $\begin{array}{l}\text { e.g.Hartman and Schmidt (1995); } \\
\text { McAlexander and Koenig (2001); } \\
\text { Pedro et al. } 2018\end{array}$ \\
\hline & Initiation & & 21 & $\begin{array}{l}\text { e.g. Martin et al. (2015); } \\
\text { McAlexander and Koenig (2012) }\end{array}$ \\
\hline & $\begin{array}{l}\text { Facilities and } \\
\text { environment }\end{array}$ & & 15 & $\begin{array}{l}\text { e.g.Helgesen and Nesset (2007); } \\
\text { Elliott and Healy (2001) }\end{array}$ \\
\hline \multirow[t]{5}{*}{$\begin{array}{l}\text { Commitment } \\
\text { indicators }\end{array}$} & To give back & & 42 & $\begin{array}{l}\text { e.g.Weerts and Ronca (2007); } \\
\text { Weerts et al. (2010); } \\
\text { Iskhakova et al. (2016) }\end{array}$ \\
\hline & & Recommendation & 7 & $\begin{array}{l}\text { e.g. Bernal and Mille (2013); Pedro } \\
\text { et al. (2020); Pedro et al. (2018); } \\
\text { Wilkins and Huisman (2014) }\end{array}$ \\
\hline & & $\begin{array}{l}\text { To share } \\
\text { experience }\end{array}$ & 5 & $\begin{array}{l}\text { e.g. Iskhakova et al. (2016); } \\
\text { McAlexander and Koenig (2001) }\end{array}$ \\
\hline & Further Training & & 21 & $\begin{array}{l}\text { e.g. Helgesen and Nesset (2007); } \\
\text { McAlexander and Koenig (2001); } \\
\text { Schlesinger et al. (2016) }\end{array}$ \\
\hline & $\begin{array}{l}\text { Pride } \\
\text { (Associated with } \\
\text { the sense of } \\
\text { belonging) }\end{array}$ & & 16 & $\begin{array}{l}\text { e.g. Hennig- Thurau et al. (2001); } \\
\text { McAlexander and Koenig (2001); } \\
\text { Nora and Cabrera (1993); } \\
\text { Mael and Ashforth (1992) }\end{array}$ \\
\hline Current situation & Constraints & & 21 & $\begin{array}{l}\text { e.g. Newman and Petrosko (2011); } \\
\text { Belfield and Beney (2000) }\end{array}$ \\
\hline \multirow[t]{3}{*}{ HEI's commitment } & $\begin{array}{l}\text { Training } \\
\text { development }\end{array}$ & & 18 & e.g. Schlesinger et al. (2016) \\
\hline & Solicitations & & 7 & $\begin{array}{l}\text { e.g Skari (2014); } \\
\text { Belfield and Beney (2000) }\end{array}$ \\
\hline & Communication & $\begin{array}{r}\text { Obligation } \\
\text { to listen }\end{array}$ & 7 & Bernal and Mille (2013) \\
\hline
\end{tabular}

their time in classes and in permanent contact with their teachers, who play a key role in their instruction. Teachers are the "visible face" of the instruction system, and the literature underscores issues like quality of teaching; teaching methods; pedagogical quality; instructional effectiveness; teachers' ability, which may influence satisfaction and image determinants of student/alumni loyalty (Helgesen and Nesset 2007; Pedro et al. 2018). Our findings bring interesting issues to the general discussion concerning an RM framework. They underline the teachers' key role in the process, which goes 


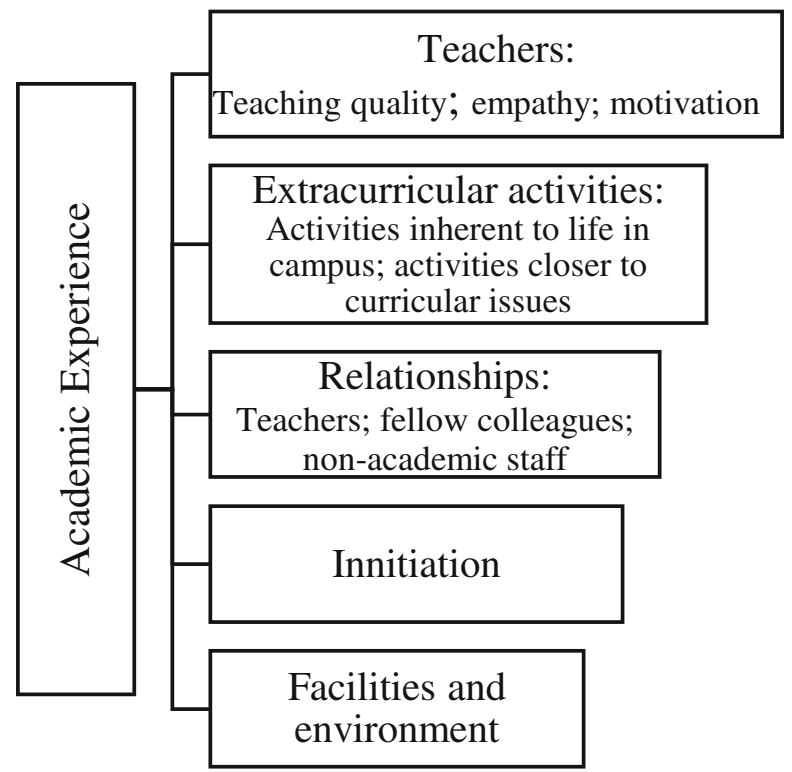

Fig. 1 Academic experience. Categories' hierarchy

beyond the academic instruction to high quality human interactions (Elsharnouby 2015), and simultaneously allows a deeper clarification of the variable itself, revealing that teachers play an important role in their evolution as human beings. Even the hard work and tough challenges they were faced with are seen now as something decisive for their personal growth and, therefore, as very valuable. McAlexander and Koenig (2001) also refer this issue as a determinant for alumni loyalty.

Extracurricular activities seem to have a deep influence on their memories, and positive feelings arise. It is worthwhile to mention the achievements resulting from those activities that seem to influence the positive feelings.

For analysis, were considered the activities inherent to students' organizations and volunteer work as well as those under the curricular scope. Examples of the former activities reveal a great involvement in the life on campus as an instance in academic association and in the academic musical group (Tuna) as well as in other specific campus groups. On the other hand, experiences in the second type of activities are now recognized as determinant to their development as human beings and future professionals.

G1. I5 "[...]As a member of the academic association I was allowed to participated in many activities in other institutions... and I must confess that almost $90 \%$ of my life as a student university was spend in the "Tuna", it offered me the chance to develop decisive soft skills."

G3. I9 "[...]It was important for me to be a member of AIESEC. That experience allowed me to open my mind[...]"

G1. I12 "[...] the most exciting moments I remember, were when I had the chance to participate in an international conference of tourism students in Madrid... those moments were very important for us[...]" 
Extracurricular activities are frequently mentioned in literature as strong antecedents of alumni giving (e.g. Clotfelter 2001; Gaier 2005; Newman and Petrosko 2011). Those activities allow students to develop their sense of responsibility, to benefit from extra learning that is not achieved at the classroom level and provide them with several interactions that help their development as citizens (Skari 2014) and they also involve a considerable amount of fun (McAlexander and Koenig 2001). Martin et al. (2015) mentioned that those students who are active in university activities tend to become more active and engaged alumni in the future. Astin (1984, p. 518) refers to student involvement as "[...] the amount of physical and psychological energy that the student devotes to the academic experience. Thus, a highly involved student is one who, for example, devotes considerable energy to studying, spends much time on campus, participates actively in student organizations, and interacts frequently with faculty members and other students".

Our findings underline these issues, but we also can discern a sense of pride to be a co-producer of the service. The student, as a co-producer of the educational service, has long been a focus of attention. Litten (1980) has already spoken about students as a part of the process of education, adding that benefits and satisfaction in this process depend on the skills, abilities and resources students bring to the process. Throughout the years, studies (Elsharnouby 2015; Harvey 1996; Schlesinger et al. 2015) are conducted providing insights that may help to find performance indicators, such as student satisfaction and the fulfilment of their expectations, as well as programmes, corporate image and learning outcomes. However, the core question related to student co-creation still lacks development (Elsharnouby 2015).

Relationships also play an important role in academic experience, as a decisive influence during their lives as students and afterwards. Some of them mentioned that they still maintain deep relationships with some teachers, either by the collaboration they give in seminars, workshops, other activities or simply by keeping in touch with them. Likewise, they appreciate the fact that teachers trusted and respected them; they felt important, which leads now to the maintenance of strong relationships. Relationships with fellow colleagues and with non-academic staff are also stressed as strong issues in the definition of pleasant memories.

G1. I5 "I try to maintain a relationship with some teachers to understand what is going on here, I try to keep in touch to keep updated"

G1. I4 "For me, living together is what comes to my mind and my heart was the relationship with people, with colleagues[...]"

Students' lives are strongly marked by all the interactions they develop in the learning process and connected activities. All kinds of relationships that they develop determine their feelings towards the alma mater. In an RM point of view, this is a core issue, and it has been emphasized in literature. Long-term relationships, such as the ones students develop during their academic life, may frame the way they assess and perceive the institution (Gaier 2005; McAlexander and Koenig 2001). Moreover, Skari (2014) also underlines relationships with staff and with faculty as predictors of alumni giving, and other studies point out the importance of quality student-professor interaction as an antecedent of satisfaction and image (e.g. Hartman and Schmidt 1995; Schlesinger et al. 2015). 
Initiation was a dimension identified in academic experience as decisive in their memories. It underlines an experience itself, which comprises different features: fear; integration; and relationships.

G1. I4 "I remember the first freshman reception. I was very scared I was never scolded, but I was very scared anyway. It was certainly a moment to remember[...]"

G1. I5 "[...]without initiation activities it would not be the same thing... I was hearing about the reception to the freshman and I only remember people's shoes[...]"

As determinants of student and alumni loyalty, tradition and rituals such as freshmen initiation activities deserve some reflection, as they may influence student integration and further engagement in campus life. Martin et al. (2015) stressed that universities should consider tradition and rituals, where those activities are included, as a means to foster student and, later on, alumni commitment. McAlexander and Koenig (2012) enhancing the role of brand community in HEIs, describing the shared tradition and rituals as a part of it and how the sense of belonging to the community will influence the support behaviour and the interactions between members. Mael and Ashforth (1992) mentioned how rituals and traditions can be important to enhancing identity and stressed that individuals who identify with the organization very likely will support the organization.

Facilities and environment were also remembered as underlying positive references.

G1. I4 "The library was definitely my second house[...]"

G1. I5 "I have two places that I fully remember all my student time: the library and the RFA (a student PUB)...even the surrounding environment of the city[...]"

G1. I11 "I remember a lot the several dinners in the canteen[...]"

References to facilities appear currently in literature as drivers for dimensions like satisfaction, quality, image, etc. simultaneously, references to available resources (e.g. library, computer services, study rooms, laboratories) are likely named as evaluation indicators in AE (e.g. Astin 1984; Duarte et al. 2010; Elliott and Healy 2001)

Likely, environment features seem to play a key role in student satisfaction. Participants mentioned the nearby city and the general region itself, stressing cultural and entertainment aspects, available services and the climate as some examples of the good conditions offered. Pedro et al. (2016) describe a tight connection between a student's relationship with the external and internal campus environment and the quality of AE. However, references to the university physical environment do not appear much in literature as a crucial aspect of student/alumni assessment. Further research on this matter may give interesting clues.

Commitment Indicators. Commitment Indicators were explored through Q.2, although in several comments related to other questions, commitment indicators were identified. Three main categories are shown in Fig. 2.

The willingness to give back appeared in expressions stressing variables like: support; advocacy; mentoring; and all sorts of participation. However, the variables 


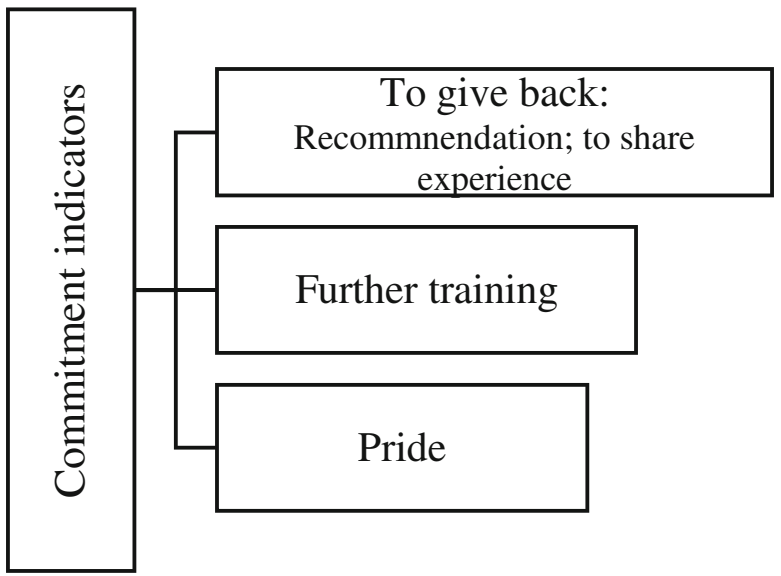

Fig. 2 Commitment indicators. Categories' hierarchy

of recommending and sharing experience were the ones most mentioned. The sense of duty for giving back is perceived and mentioned during the conversation, explained by the fact that they feel grateful for what they received. It is noteworthy to mention that this concept is also likely associated with "come back", which is stressed by the majority of participants, and a significant amount of nostalgia was identified. Although sometimes they couldn't find a clear reason to return they stressed, however, the desire to be involved. The come back can assume different facets, either to give a slight collaboration, to a mere visit, to do training or to give their support wherever the institution needs.

G1. I5 "[...] I feel the need to repay a little of what I was given ... That's why I always accept university invitations because it's the way a have to give back."

G2. I7 "I recommend the university $[\ldots .$.$] "$

G3. I2 "[...] I really do not mind giving my contribution according to my experience...to help in promoting visits to my company as a start $[\ldots] "$

Widely treated in literature, being the following studies some examples Belfield and Beney (2000); Clotfelter (2003); Daly (2013); Diamond and Kashyap (1997); Tom and Elmer (1994); Weerts and Ronca (2007) the concept alumni giving back holds diverse meanings. Charitable giving is a common example of alumni support that has been deeply studied. Alumni financial support is an important help in an environment of public budgeting constraints ${ }^{1}$ (Belfield and Beney 2000; Clotfelter 2003). However, alumni influence and support goes beyond charitable giving. Volunteer behaviours play a key role in what alumni support is concerned with, producing enrichment to all activities with which they might be involved and underline an altruistic behaviour that

\footnotetext{
${ }^{1}$ American Colleges and Universities received \$11.37 Billion in alumni gifts, $14.5 \%$ of the total amount of fundraising (CAE 2018). The European reality is, nevertheless, different. Fundraising with alumni still lacks development as well as the sense of a donor culture. However, there is the exception, the UK, where some universities generate close to $10 \%$ of philanthropic fundraising (Estermann and Pruvot 2011).
} 
may evolve to other stages of giving. Alumni can be excellent recruiters, lend their experience and expertise to improve academic programmes ${ }^{2}$ and may serve as mentors (Weerts et al. 2010). Their professional and personal networking is a useful means to alma mater advocacy and support (Iskhakova et al. 2016).

Recommendation and the will to share their experience usually appear in literature as drivers for alumni commitment and constitute two references of the value alumni can provide to their alma mater (e.g. Helgesen and Nesset 2007; Hennig-Thurau et al. 2001; Pedro et al. 2020; Pérez-Esparrells and Torre 2012). Recommendation is an excellent aid to build enrolments and a cheap way of advertising. Transferring their experience and expertise may express a way of contributing to enhancing corporate quality and consequent prestige and reputation. Alumni are aware that they also benefit from this process.

Further training is mentioned by some participants, as a way to come back.

G1. I4 "... I do think doing a postgraduate or master's degree in the near future..."

G2. I15 "...I consider that is important from time to time to come back and review theoretical concepts... I would like to review a set of subjects, make a refresh, because there are important aspects at academic level that might help us at work..."

The investment in additional academic and professional education is a common way to come back and a proof of loyalty (Helgesen and Nesset 2007; McAlexander and Koenig 2001; Schlesinger et al. 2016). Seen under the scope of repeat purchasing behaviour (Dick and Basu 1994), it gives insights into loyalty and all its inherent premises. But if we take into consideration the implied concern of training quality improvement and the expressed availability to help through their experience and expertise, there is a stream of commitment relationship that gathers different concepts, such as co-producer (Elsharnouby 2015; Wikström 1995); partnership (Sperlich and Spraul 2007); involvement (Newman and Petrosko 2011); and effort on behalf of the group (Mael and Ashforth 1992).

The words pride and proud were mentioned mostly by those who were involved in several activities during their academic experience, and particularly in a very enthusiastic way. The feeling of belonging to a group was referred to.

G2. I5 "I always felt a huge pride reading the name of the university at the main entrance ... it was a privilege of being of this institution and I still feel it[...]"

G3. I9 "[...] I'm proud of studying here...I'm proud of the institution....

Whenever there is news about accomplishments make me very proud about it $[\ldots]^{\prime \prime}$

\footnotetext{
${ }^{2}$ The possibility of giving their help to improve some of aspects in terms of courses' curricula through their skills and experience was described. The quality of training is a concern shown by most of the participants when it comes to the match between the needs of the labour market and what the institution offers.
} 
Pride is an emphatic element in commitment-relationship, it reflects positive and consistent outcomes of a relationship, and it is associated with: an emotional attachment in the relationship and to the sense of belonging and share of values, leading to organizational identification and the perception of oneness with or belongingness to an organization (Mael and Ashforth 1992; Tom and Elmer 1994; Wilkins and Huisman 2013). Some studies refer to loyalty to the institution, and the sense of belonging or maintaining membership in the institution (Nora and Cabrera 1993) or affiliation with the institution (Mael and Ashforth 1992). Hennig-Thurau et al. (2001) refer to emotional commitment as a central construct to explain student loyalty. This construct encompasses, among other items, two expressing pride related to the university and to the course. However, research towards a deeper understanding of the concept and the respective consequences is needed.

Current situation. Answers to Q.3 present the constraints to collaboration shown in Fig. 3.

However, all the participants described their will to participate and collaborate whenever they are asked, and stressed their availability to cooperate, despite some constraints.

G1. I1 "Whenever I am invited, I'm very pleased to collaborate [...]"

G3. I9 "[...] as long as there are requests for collaboration $[\ldots] "$

G2. I15 "It's up to the university to ask for my collaboration...Usually

when the university asks for my collaboration for whatever it is necessary,

I accept the invitation."

Research commonly describes the current situation to explain alumni donations, because it includes a considerable number of determinants (social, personal, cultural, professional, demographic, etc.). Several studies refer to it (e.g. Belfield and Beney 2000; Clotfelter 2001; Newman and Petrosko 2011), stressing a perspective of charitable giving which compels one to consider the income factor as a common determinant. This study's approach is not charitable giving hence, answers are given bearing in mind non-monetary support. Work,

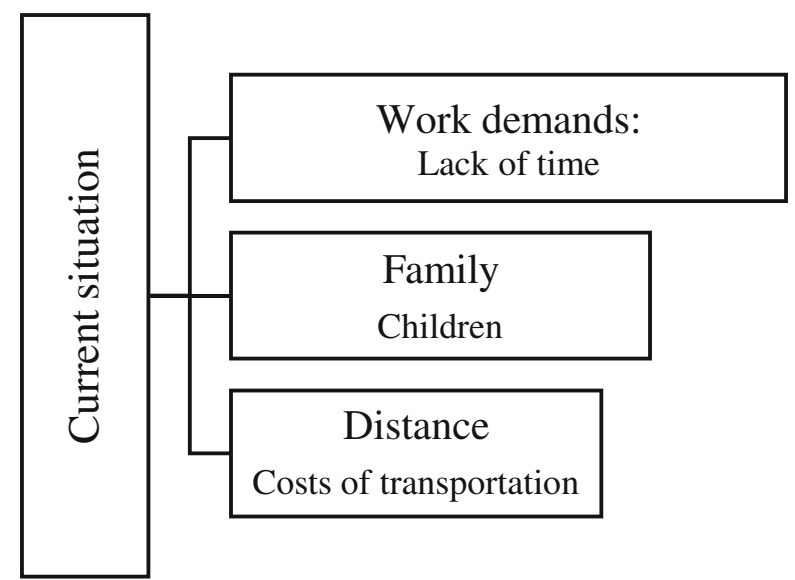

Fig. 3 Current situation. Categories' hierarchy 
family and place of residence are some constraints pointed out, but are not stressed as limits to their support, and participants underline their will to cooperate instead. This perspective raises further questions. For a start, HEIs must deeply explore the availability to cooperation. This thought takes us to a key point, much mentioned by participants: solicitation, which is described in the next section.

HEI's commitment. Finally, Q.4 aimed to capture participants' opinions about what is expected from the university in the commitment-relationship. HEIs have a huge responsibility in conducting this process. Opinions focused on three main aspects, shown in Fig. 4.

Regarding training development, many demand quality improvements of the courses and post-graduation. The crucial role the university must play in its environment was stressed. Although this remark had a strong professional basis (all the participants are working in the region, some are entrepreneurs, and others are workers in important and big companies), the feeling of obligation to contribute to the quality was common.

G3. I2 "I think there is a lot that can be done to bring former students to university in terms of training. Training alternatives responding to current needs of the labor market must be provided [...]"

G3. I3 "[...] university must be more involved with the community, it shall promote the practical component of the courses... I hope there is a closer connection to the job market $[\ldots] "$

Describing solicitations, alumni expect that the HEI will ask for their contribution. The message they transmit (even though sometimes subtle) is that they are important, available to collaborate and the alma mater just has to ask.

G1. I1 "Whenever I am invited, I'm very pleased to collaborate [...]"

G3. I9 "[...] as long as there are requests for collaboration [...]"

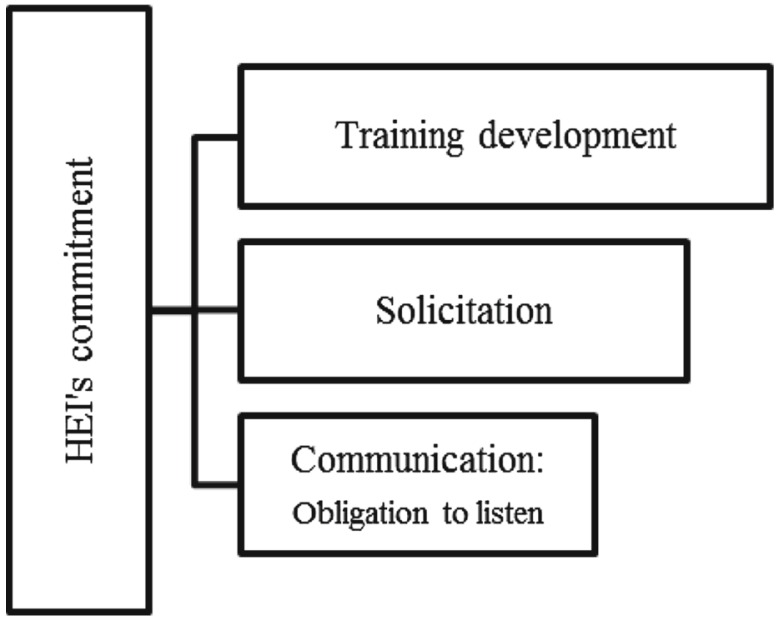

Fig. 4 HEI's Commitment. Categories' hierarchy 
G2. I15 "It's up to the university to ask for my collaboration...Usually

when the university asks for my collaboration for whatever it is necessary, I accept the invitation."

Communication was described as crucial to involvement, as well as the need to improve communication strategies. Furthermore, this dimension is quite connected to the obligation to listen, which was often mentioned as they feel that alma mater forgets its former students. The fact that they have very important information to deliver, experiences to share and contributions to give towards the development of the institution were used as arguments for the need to build and reinforce channels to active listening.

G2. I17 "There should be a better communication with the community [...]"

G2. I19 " Communication with students has to be improved, namely the one sent by email...the university's website should also be revised...to strength image [...]"

G1. I5 "I hope university has the ability to listen to us, I expected at the very least to be heard $[\ldots]^{\prime \prime}$

Literature underlines the role HEIs play in fostering the relationship with their alumni (e.g. McAlexander and Koenig 2001; Pedro et al. 2020; Skari 2014). Skari (2014) refers to strategies to keep alumni connected and engaged; community-building efforts to connect alumni and to build relationships; and promotion of events and publications and solicitation strategies. Bernal and Mille (2013) suggest initiatives towards alumni engagement regarding the following dimensions: communication, loyalty and social, professional interactions. McAlexander and Koenig (2001) advise marketers to bet on trusting relationships with alumni, showing them that the institution values their opinions. Moreover, authors also stressed the need to assess alumni communications and activities, bearing in mind the reinforcement of alumni connections and relationship reciprocity through customer relationship marketing applications.

When it comes to solicitations issues, it is a fertile field. Skari (201, p. 24) describes "people give because they are asked", and thus institutions need to improve their ability to ask. Alumni must understand the purposes of solicitations, otherwise these have no effectiveness (Belfield and Beney 2000). These concepts were developed regarding charitable giving however, they apply perfectly to non-monetary giving.

\section{Conclusions}

The alumni-alma mater commitment-relationship is a dynamic process and fed by many sources. Four main dimensions define the theoretical basis: academic experience; current situation; commitment indicators; and HEI's commitment.

Prior to any objective conclusion, it is important to mention the enthusiastic involvement of the focus group participants, simply because the call was about their alma mater. A significant amount of nostalgia was also common, and generally, positive feelings emerged along conversation. Bearing in mind that objectives one and two aimed to promote dialogue to capture alumni's opinions about topics related to commitment and at the same time demonstrating this technic as useful to get them involved we believe that results achieved accomplished these objectives. This is 
particularly significant in the HEI studied, in which the first steps to develop an alumni culture are been taken.

Participant's responses at each dimension revealed useful information for further developments. Memories about their time as students revealed that their interactions with teachers and the empathy and motivation towards students are strong reasons to keep in touch with some of the teachers. Extracurricular activities and inherent accomplishments were mentioned as important at that time, along with all the fun those moments provided, which ultimately contribute to fostering relationships that are strongly embedded in their memories. Initiation of freshman remains in their memories but does not gather consensus. Some remember it as funny moments and a good aid for integration, while a few talk about it in a negative way. Places, facilities and environments came into the discussion as well, and also underlie positive references.

When the question about their current situation was posed, constraints about lack of time and work demands appear to be the main reasons for limiting their participation, although they all stressed their will to collaborate and underlined the HEI's solicitations as crucial to leveraging their engagement. Indeed, solicitations appear among drivers in HEI's commitment, revealing a challenging task that HEIs must include in their strategies. Moreover, structured and consistent communication with alumni seems to be a crucial starting point to achieve positive outcomes in this relationship. The institution's responsibilities were pointed out, and they increase when the HEI assumes the role of listener, transmitting a clear sign of recognition of its alumni's importance. Maintaining training quality was also mentioned as a determinant on this commitment relationship. Alumni are aware that training quality has a key role in HEI's prestige, meaning potential personal and professional benefits for them, too. This may explain their concern about it and highlight their availability to help in this process.

Finally, concerning indicators of alumni commitment, a common sense of duty to give back what they received seems to mark their commitment. The concept to come back often appeared during the conversation associated with that duty, underlining a significant amount of nostalgia and denoting will to participate, collaborate and give support whenever it is needed.

Regarding giving back, recommendation and the share of their experience stood out, and both encompass a deep sense of value that alumni can provide to their alma mater.

The willingness to get further training emerged not only as a means for academic valorisation, but also as a way to be involved again and a reinforcement of their sense of belonging, as was very much pronounced through several references to pride. Indeed, this feeling arises as one attribute for alumni commitment, emphasizing a consistent starting point for a relationship, but giving the university strong reasons to conduct this process with caution. Regarding third objective of this study, to achieve information about drivers and consequences of commitment permitting to draw a theoretical framework, we believe that above mentioned conclusions allow us to consider that this objective was met.

The next section presents some implications resulting from these findings.

\subsection{Implications}

HEIs are given a set of challenges and opportunities for improvement through findings in this study, namely, the ones related to academic experience and HEI's 
commitment. Implementing measures aiming the enhancement of student engagement will guarantee engaged alumni in the future; enhancement of student/alumni satisfaction; and prestige and a positive image. The involvement of all direct intervenient of the educational process in these activities should be a concern when designing strategies. Follow some suggestions:

(1) Academic reputation of professors plays an important role in student's perceived image, but that reputation is a complex construct that justifies a deeper study by itself. Yet, continuous efforts to teaching quality improvement must be done, because training is the main service students require. Empathy and motivation in a relational marketing perspective demand coherent messages towards professors, enhancing the importance students give to those attributes, and shall emphasize the key role professors have in the educational process.

(2) Regarding extracurricular activities, university officials must implement practices to encourage enrolment in non-academic activities. Even academic activities developed outside the classroom have a strong impact on student development, and consequently, strategies must be devoted to the reinforcement of these activities in every training programme.

(3) The relationships students foster influence their future involvement with the alma mater, and therefore they must be cultivated (McAlexander and Koenig 2001). Every event, activity, and communication campaign must be prepared under this scope.

(4) Effective communication channels should be a priority, to give HEIs the necessary abilities to relate with their students/alumni, especially to treat their feedback in an efficient way.

(5) Initiation activities should be considered within integration strategies.

(6) A permanent assessment of training quality must underline strategic planning.

(7) Every effort to enhance organizational culture should raise pride and sense of belonging.

\subsection{Limitations and suggestions for further studies}

This study has some limitations, which pave the way for further studies, as follows:

(1) This study was applied to only one institution. To assure generalization of findings, this study should be applied to other similar HEIs.

(2) The sample comprised a diversity of alumni features, which do not allow a comparison between different groups. A further study, selecting homogeneous groups, could provide interesting data leading to identification of clusters.

(3) The scope of the study comprised four dimensions, each of which allowed generic findings. Regarding the key role of each, an in-depth study for every dimension is worthy.

(4) The study took place in a certain period of time, and thus it gives a static perception of reality. A longitudinal study over time could map alumni perceptions and behaviours, permitting researchers to observe how these topics evolve. 
(5) The findings remain at the understanding level of the perceptions and judgments participants make about the topics and they help to develop ideas and hypotheses. Further quantitative studies would provide deeper insights through the examination of the relationships between and among variables, and generalize results from a larger sample of alumni.

\section{References}

Alnawas, I., \& Phillips, C. (2015). Alumni orientation: Development of the construct. Journal of Nonprofit \& Public Sector Marketing, 27(2), 183-215.

Alves, H., \& Raposo, M. (2007). Conceptual model of student satisfaction in higher education. Total Quality Management \& Business Excellence, 18(5), 571-588.

Alwi, S. F., \& Kitchen, P. J. (2014). Projecting corporate brand image and behavioral response in business schools: Cognitive or affective brand attributes? Journal of Business Research, 67(11), 2324-2336.

Amani, Z. (2015). Commitment as a mediator of the relationship between trust and relationship loyalty to retailer. Journal of Business Studies Quarterly, 6(3).

Astin, A. W. (1984). Student involvement: A development theory for higher education student involvement: A developmental theory for higher education. Journal of College Student Development, 40(5), 518-529.

Bardin, L. (1977). Análise de Conteúdo [L’Analyse de Contenu]. Lisboa: Edições 70.

Belfield, C. R., \& Beney, A. P. (2000). What determines alumni generosity? Evidence for the UK the UK. Education Economics, 8(1), 65-80.

Bernal, A., \& Mille, D. (2013). Initiating alumni engagement initiatives: Recommendations from MFT alumni focus groups. Contemporary Family Therapy, 36, 300-309.

Bleiklie, I., Enders, J., \& Lepori, B. (2012). Introduction: Transformation of universities in Europe. Higher Education, 65, 123-124. https://doi.org/10.1007/s10734-012-9577-5.

Brown, R. M., \& Mazzarol, T. W. (2008). The importance of institutional image to student satisfaction and loyalty within higher education. Higher Education, 58(1), 81-95.

Browne, B. A., Kaldenberg, D. O., Browne, W. G., \& Brown, D. J. (1998). Student as customer: Factors affecting satisfaction and assessments of institutional quality. Journal of Marketing for Higher Education, $8(3), 1-14$.

Bryman, A. (2012). Social research methods (4th ed.) New York: Oxford University Press.

CAE. Council for Aid to Education, (2018). Colleges and Universities raised \$ 43.60 Billion in 2017. Retrieved April 17, 2018 from http://cae.org/images/uploads/pdf/VSE-2017-Press-Release.pdf

Canterbury, R. M. (2000). Higher education marketing: A challenge. Journal of Marketing for Higher Education, 9(3), 15-24.

Clark, K. R., \& Vealé, B. L. (2018). Strategies to enhance data collection and analysis in qualitative research. Radiologic Technology, 89(5), 482-485.

Clotfelter, C. T. (2001). Who are the alumni donors? Giving by two generations colleges. Nonprofit Management \& Leadership, 12(2), 119-138.

Clotfelter, C. T. (2003). Alumni giving to elite private colleges and universities. Economics of Education Review, 22(2), 109-120.

Conway, T., Mackay, S., \& Yorke, D. (1994). Strategic planning in higher education: Who are the customers? International Journal of Educational Management, 8(6), 29-36.

Daly, S. (2013). Philanthropy, the new professionals and higher education: The advent of directors of development and alumni relations. Journal of Higher Education Policy and Management, 35(1), 21-33.

Diamond, W. D., \& Kashyap, R. K. (1997). Extending models of prosocial behavior to explain University alumni contributions. Journal of Applied Social Psychology, 27(10), 915-928.

Dick, A. S., \& Basu, K. (1994). Customer loyalty: Toward an integrated conceptual framework. Journal of the Academy of Marketing Science, 22(2), 99-113.

Donina, D., \& Hasanefendic, S. (2018). Higher Education institutional governance reforms in the Netherlands, Portugal and Italy: A policy translation perspective addressing the homogeneous / heterogeneous dilemma. Higher Education Quarterly. 1-16. https://oi.org/10.1111/hequ.12183

Duarte, P. O., Alves, H. B., \& Raposo, M. B. (2010). Understanding university image: A structural equation model approach. International Review on Public and Nonprofit Marketing, 7(1), 21-36. 
Elliott, K. M., \& Healy, M. A. (2001). Key factors influencing student satisfaction related to recruitment and retention. Journal of Marketing for Higher Education, 10(4), 1-11.

Elliott, K. M., \& Shin, D. (2002). Student satisfaction: An alternative approach to assessing this important concept. Journal of Higher Education Policy and Management, 24(2), 197-209.

Elsharnouby, T. H. (2015). Student co-creation behavior in higher education: The role of satisfaction with the university experience. Journal of Marketing for Higher Education, 1241, 1-25.

Estermann, T., \& Pruvot, E. B. (2011). Financially sustainable universities II. European University Association: European universities diversifying income streams Retrieved from: http:/www.eua. be/Libraries/publications-homepage-list/Financially_Sustainable_Universities_II_-_European_ universities_diversifying_income_streams.pdf?sfvrsn $=2$.

Fullerton, G. (2003). When does commitment Lead to loyalty? Journal of Service Research, 5(4), 333-344.

Gaier, S. (2005). Alumni satisfaction with their undergraduate academic experience and the impact on alumni giving and participation. International Journal of Educational Advancement, 5(4), 279-288.

Gallo, M. (2012). Beyond philanthropy: Recognizing the value of alumni to benefit higher education institutions. Tertiary Education and Management, 18(1), 41-55.

Geyskens, I., SteeKamp, J. B., Scheer, L., \& Kumar, N. (1996). The effects of trust and interdependence on relationship commitment: A trans- Atlantic study. International Journal of Research in Marketing, 13, 303-317.

Grönroos, C. (1994). From marketing mix to relationship marketing: Towards a paradigm shift in marketing. Management Decision, 32(2), 1-27.

Grossman, R. P. (1999). Relational versus discrete exchanges: The role of trust and commitment in determining customer satisfaction. The Journal of Marketing Management., 9(2), 47-58.

Guerra, I.C. (2006). Pesquisa Qualitativa e Análise de Conteúdo- Sentidos e formas de uso [Qualitative research and content analysis- purposes and ways of use]. Cascais. Princípia Editora.

Hartman, D. E., \& Schmidt, S. L. (1995). Understanding student/alumni satisfaction from a consumer's perspective: The effects of institutional performance and program outcomes. Research in Higher Education, 36(2), 197-217.

Harvey, J. A. (1996). Marketing schools and consumer choice. International Journal of Educational Management, 10(4), 26-32.

Helgesen, Ø. (2008). Marketing for higher education: A relationship marketing approach. Journal of Marketing for Higher Education, 18(1), 50-78.

Helgesen, Ø., \& Nesset, E. (2007). Images, satisfaction and antecedents: Drivers of student loyalty? A case study of a Norwegian University college. Corporate Reputation Review, 10(1), 38-59.

Hemsley-Brown, J., \& Oplatka, I. (2006). Universities in a competitive global marketplace. A systematic review of the literature on higher education marketing. International Journal of Public Sector Management, 19(4), 316-338.

Hennig-Thurau, T., Langer, M. F., \& Hansen, U. (2001). Modeling and managing student loyalty: An approach based on the concept of relationship quality. Journal of Service Research, 3(4), 331-344.

Henning, G. W. (2012). Leveraging student engagement for student and institutional success. About Campus, $17(4), 15-18$.

Huselid, M. A., \& Day, N. E. (1991). Organizational commitment, job involvement, and turnover: A substantive and methodological analysis. Journal of Applied Psychology, 76(3), 380-391.

Iskhakova, L., Hilbert, A., \& Hoffmann, S. (2016). An integrative model of alumni loyalty-An empirical validation among graduates from German and Russian universities. Journal of Nonprofit \& Public Sector Marketing, 28(2), 129-163.

Koenig-Lewis, N., Asaad, Y., Palmer, A., \& Petersone, E. (2016). The effects of passage of time on alumni recall of 'Student Experience'. Higher Education Quarterly, 70(1), 59-80.

Kotler, P., \& Fox, K. F. A. (1994). Marketing estratégico para instituições educacionais [strategic marketing for educational institutions]. São Paulo: Editora Atlas.

Litten, L. (1980). Marketing higher education: Benefits and risks for the American academic system. The Journal of Higher Education, 51(1), 40-59.

Mael, F., \& Ashforth, B. (1992). Alumni and their alma mater: A partial test of the reformulated model of organizational identification. Journal of Organizational Behavior, 13, 103-123.

Mainardes, E. W., Raposo, M., \& Alves, H. (2014). Universities need a market orientation to attract nontraditional stakeholders as new financing sources. Public Organization Review., 14(2), 159-171.

Martin, M., Moriuchi, E., Smith, R., Moeder, J., \& Nichols, C. (2015). The importance of university traditions and rituals in building alumni brand communities and loyalty. International Academy of Marketing Studies Journal, 19(3), 107-119. 
Mazzarol, T. W., \& Soutar, G. N. (1999). Sustainable competitive advantage for educational institutions: A suggested model. The International Journal of Educational Management, 13(6), 287-300.

McAlexander, J. H., \& Koenig, H. F. (2001). University experiences, the student-college relationship, and alumni support. Journal of Marketing for Higher Education, 10(3), 21-44.

McAlexander, J. H., \& Koenig, H. F. (2012). Building communities of philanthropy in higher education: Contextual influences. International Journal of Nonprofit and Voluntary Sector Marketing, 17, 122-131.

McAlexander, J. H., Kim, S. K., \& Roberts, S. D. (2003). Loyalty: The influences of satisfaction and brand community integration. Journal of Marketing of Theory and Practice, 11(4), 1-11.

Morgan, R. M., \& Hunt, S. D. (1994). The commitment-trust theory of relationship marketing. Journal of Marketing, 58(July), 20-38.

Mowday, R. T., Steers, R. M., \& Porter, L. W. (1979). The measurement of organizational commitment. Journal of Vocational Behaviour, 14, 224-247.

Newman, M. D., \& Petrosko, J. M. (2011). Predictors of alumni association membership. Research in Higher Education, 52(7), 738-759.

Nora, A., \& Cabrera, A. F. (1993). The construct validity of institutional commitment: A confirmatory factor analysis. Research in Higher Education, 34(2), 243-262.

Oplatka, I., \& Hemsley-Brown, J. (2007). The incorporation of market orientation in the school culture: An essential aspect of school marketing. International Journal of Educational Management, 4, 292-305.

Pedro, I., \& Andraz, J. (2019). Alumni commitment in higher education Institutions: Determinants and Empirical Evidence. Journal of Nonprofit \& Public Sector Marketing, https://doi.org/10.1080 /10495142.2019.1656138.

Pedro, E., Leitão, J., \& Alves, H. (2016). Does the quality of academic life matter for students' performance, loyalty and university recommendation? Applied Research in Quality of Life, 11, 293-316.

Pedro, I., Pereira, L., \& Carrasqueira, H. (2018). Determinants for the commitment relationship between alumni and the Alma mater. Journal of Marketing for Higher Education, 28(1), 128-152.

Pedro, I., Mendes, J., \& Pereira, L. (2020). Understanding alumni-Alma mater commitment relationships upstream and downstream. Journal of Marketing for Higher Education, 1-22. https://doi.org/10.1080 /08841241.2020.1768200.

Pérez-Esparrells, C., \& Torre, E. M. (2012). The challenge of fundraising in universities in Europe. International Journal of Higher Education, 1(2), 55-66.

Ravald, A., \& Grönroos, C. (1996). The value concept and relationship marketing. European Journal of Marketing, 30(2), 19-30.

Rojas-Méndez, J., Vasquez-Parraga, A. Z., Kara, A., \& Cerda-Urrutia, A. (2009). Determinants of student loyalty in higher education: A tested relationship approach in Latin America. Latin American Business Review, 10(1), 21-39.

Saldaña, J. (2009). The coding manual for qualitative researchers. California: Thousand Oaks Retrieved from: http://stevescollection.weebly.com/uploads/1/3/8/6/13866629/saldana_2009_the-coding-manual-forqualitative-researchers.pdf.

Sargeant, A., \& Woodliffe, L. (2005). The antecedents of donor. Nonprofit Management \& Leadership, 16(1), 61-78.

Schlesinger, W., Cervera, A., \& Iniesta, M. A. (2015). Key elements in building relationships in the higher education services context. Journal of Promotion Management, 21(4), 475-491.

Schlesinger, W., Cervera, A., \& Pérez-Cabañero, C. (2016). Sticking with your university: The importance of satisfaction, trust, image, and shared values. Studies in Higher Education, 5079, 1-17. https://doi. org/10.1007/s11218-019-09488-4.

Skari, L. (2014). Community college alumni: Predicting who gives. Community College Review, 42(1), 2340.

Snijders, I., Wijnia, L., Rikers, R., \& Loyens, S. (2019). Alumni loyalty drivers in higher education. Social Psychology of Education, 22(3), 607-627.

Sperlich, A. M. A., \& Spraul, K. (2007). Students as active partners: Higher education management in Germany. The Innovation Journal: The Public Sector Innovation Journal, 12(3), 1-19.

Stake, R. E. (1995). The art of case study research. Thousand Oaks, California: Sage Publications.

Stemler, S. (2001). An overview of content analysis. Practical Assessment, Research \& Evaluation, 7(17), 137-146.

Tom, G., \& Elmer, L. (1994). Alumni willingness to give and contribution behaviour. Journal of Services Marketing, 8(2), 57-62.

Weerts, D. J., \& Ronca, J. M. (2007). Profiles of supportive alumni: Donors, volunteers, and those who "do it all'. International Journal of Educational Advancement, 7(1), 20-34. 
Weerts, D. J., Cabrera, A. F., \& Sanford, T. (2010). Beyond giving: Political advocacy and volunteer behaviors of public university alumni. Research in Higher Education, 51, 346-365.

Wikström, S. (1995). The customer as co-producer. European Journal of Marketing, 30(4), 6-19.

Wilkins, S. \& Huisman, J. (2013). The components of student-university identification and their impacts on the behavioural intentions of prospective students. Journal of Higher Education Policy and Management, 35(6), 586-598.

Wilkins, S., \& Huisman, J. (2014). Corporate images' impact on consumers' product choices: The case of multinational foreign subsidiaries. Journal of Business Research, 67(10), 2224-2230.

Publisher's note Springer Nature remains neutral with regard to jurisdictional claims in published maps and institutional affiliations.

\title{
Affiliations
}

\section{Ilda Maria Pedro ${ }^{1,2}$ • Júlio Costa Mendes ${ }^{2,3} \cdot$ Luis Nobre Pereira ${ }^{2,4}$. Bernardete Dias Sequeira ${ }^{3,5}$}

\author{
Júlio Costa Mendes \\ jmendes@ualg.pt \\ Luis Nobre Pereira \\ Lmper@ualg.pt \\ Bernardete Dias Sequeira \\ bsequei@ualg.pt
}

1 Gabinete Alumni e Saídas Profissionais, Universidade do Algarve, Faro, Portugal

2 CinTurs- Centro de Investigação em Turismo, Sustentabilidade e Bem-Estar, Universidade do Algarve, Faro, Portugal

3 Faculdade de Economia, Universidade do Algarve, Faro, Portugal

4 Escola Superior de Gestão, Hotelaria e Turismo, Universidade do Algarve, Faro, Portugal

5 Centro Interdisciplinar de Ciências Sociais (CICS.NOVA), Évora, Portugal 